\title{
“MY WORLD IS SIGHT": H. G. WELLS'S ANTI-UTOPIAN IMAGINATION IN “THE COUNTRY OF THE BLIND”
}

\author{
Mercedes PeÑalba García \\ Universidad de Salamanca \\ mpg@usal.es
}

\section{RESUMEN}

En este artículo se analiza «El país de los ciegos» (1904) de H. G. Wells como una parábola del individuo post-darwiniano que refleja la influencia de la mitografía victoriana y de los modelos antropológicos sobre el mundo primitivo. Este cuento finisecular es un juego intelectual o jeu d'esprit, con múltiples inversiones irónicas, basado en paradigmas utópicos, evolutivos e imperialistas. La macro-estructura de este relato especulativo niega el proverbio original, subvierte la alegoría de la caverna de Platón y re-escribe el mito edénico (eu-topía). Manteniéndose fiel a las convenciones de esta tradición e invirtiendo en ocasiones su sugerente simbolismo, Wells exploró, en los inicios de su carrera literaria, temas contemporáneos complejos como el colonialismo y el imperialismo desde una perspectiva irónica. Visión y ceguera son nociones equiparables a las oposiciones binarias de supremacía y subordinación, civilización y naturaleza en esta anti-utopía (o utopía irónica) andina.

PAlabras Clave: Anti-utopía, colonialismo, primitivismo, mitografía victoriana, novela imperial / de aventuras.

\section{ABSTRACT}

This article examines H. G. Wells's «The Country of the Blind» (1904) as a parable of post-Darwinian man, influenced by Victorian mythography and anthropological models of primitivism. Drawing on utopian, evolutionary and imperialist paradigms, this fin-desiècle tale is an intellectual game or thought experiment with multiple ironic reversals. The macro-structure of this speculative story is a negation of the original proverb about the 
country of the blind, with echoes of Plato's Parable of the Cave, as well as a rewriting of the archetypal myth of a remote pastoral eu-topia. By remaining faithful to the conventions of this tradition and sometimes inverting their suggestive symbolism, the early Wells explored the complexities of colonialism and imperialism, and treated them in the ironic mode. Sight and blindness simply reverse definitions of supremacy and subordination, civilization and nature in this Andean anti-utopia (or ironic utopia).

KEYWORDS: Anti-utopia, colonialism, primitivism, Victorian mythography, adventure / imperial romance.

\section{H. G. WELLS'S FICTION IN FIN-DE-SIÈCLE BRITAIN}

First published in the April 1904 issue of the Strand Magazine, H. G. Wells's «The Country of the Blind» has been praised as «the most powerful and bitter of his short stories» (McConnell, 1981:119) and as «a magnificent example of [his] mythopoeic genius» (Bergonzi, 1961:84). This fin-de-siècle tale is a parable of post-Darwinian man, influenced by Victorian mythography and anthropological models of culture and primitivism. In the mid-to-late-nineteenth century, the new science of man, anthropology, developed notions of the primitive world that conditioned popular and scholarly understanding of myths and the function of mythic thinking.

Wells scholars commonly divide his literary career into two parts: the early Wells of scientific romances who explored the implications of evolutionary struggle and the failures of imperial civilization through ironic use of myths, and the later Wells of utopias, realist novels and discursive writings who abandoned mythopoeic thinking and irony to glorify the imperialist ethos (Bergonzi, 1961:18-22). If the nineteenth-century Wells challenged the complacency of imperialist Britain, the twentieth-century Wells expressed his faith in a progressive future as a triumph of science and technology. At a time when theories of evolution became frameworks for understanding social processes, Wells sought ways to counter the dictates of evolution - the amoral struggle for survival — by the ethical force of civilization, and often emphasized the irresolvable contradiction between the two (Hillegas, 1967:18-21; Suvin, 1979:223-25; Huntington, 1982b:8-17).

In «The Country of the Blind», H. G. Wells (1866-1946) represents the late nineteenthcentury anxieties about progress and critiques some major tenets of imperialist discoursethe moral justification for the domination of indigenous populations in the post-Darwinian world, the ambivalence of the Victorian response to nature, and technology as an unambiguous sign of progress. My reading of «The Country of the Blind» ${ }^{1}$ shows how the early Wells fictionalized the historical contexts of imperialism and colonialism, and satirized the ethos that underlay the European sense of superiority to others. Wells updated

${ }^{1}$ In the present study, I have used the original 1904 version of the story (which was reprinted in 1911, 1925, and 1927), not the 1939 revision in which H. G. Wells completely changed the ending (cf. Parrinder, 1990:71-76). All subsequent references to «The Country of the Blind» $(\mathrm{CoB})$ are to the 1911 collection of short stories and will be documented parenthetically within the text. 
the fantastic, romance narrative forms and the genre of utopia so as to explore the dominant ideology of progress in a scientific-technological age.

\section{THE ANTI-UTOPIAN MODE IN WELLS'S EARLY FICTION}

Parallel to the ideological shift from the early to the later Wells, there is a corresponding shift in the Wellsian aesthetics — the shift from anti-utopian imaginings to utopian prophesies (Huntington, 1982a:124). The anti-utopian romances of the early Wells kept the contradictions of the ethics vs. evolution dilemma alive, whereas the works of the later Wells sought utopian solutions and abandoned irony for certitude (Huntington, 1982b:139143). The split in Wells's thought expresses itself in two opposite structural principles: the utopian-dystopian mode and the anti-utopian mode. Although both forms partake of the «what if?» premise and both have the significant effect of separating us from our usual assumptions about reality (what Darko Suvin calls «cognitive estrangement»), the antiutopian mode «discovers problems, raises questions, and doubts» (Huntington, 1982a:124). Huntington argues that utopia and dystopia share a common structural pattern, although they are opposites on the surface, i.e., they present us with positive / negative visions of society: «both are exercises in imagining coherent wholes, in making an idea work, either to lure the reader towards an ideal or to drive the reader back from a nightmare» (1982a:124). In this formulation, anti-utopia is a sceptical imaginative attempt to «dismember a world», a mode of imagining that is not simply critical of the world as it is, but of the way of thought that constructs it (Huntington, 1982a:123). The essence of anti-utopia, as I am using the term here, resides in its complex vision of deeply opposing values.

The early fiction of H. G. Wells was a source of great vitality for this genre. As Bernard Bergonzi remarks, his early novels and short stories are «romances in the traditional sense, insofar as they contain an element of the marvellous, which may have a scientific - or pseudo-scientific - explanation, but which may equally originate in a supernatural happening, or in some disturbance of the individual consciousness» (1961:17). The symbolic quality of his romances and tales resembles the imaginative power of such masters of the romance and fable as Hawthorne (whose influence on his earliest work Wells acknowledged) or Kafka. In his excellent study, Scientific Romance in Britain, 1890-1950, Brian Stableford notes that «Wells began to work out the logical consequences of Darwinian theory in a series of literary thought-experiments. His stories carried great conviction, and were constructed with an imaginative power that was hitherto unparalleled» (1985:29). His early fiction is remarkably innovative in form and subject matter. The generic reversals of Wells's early romances keep his writing from complicity with the existing ideological status quo and show a desire to thwart the expectations of their implied reader (James, 2012:38).

\section{1. «The Country of the Blind»: A Journey to the Imperial Frontier}

The adventure romance (or «imperial romance», as it is sometimes termed) was an enormously popular sub-genre of fiction in Britain in the mid-1880s. Two best-selling 
novels-Robert Louis Stevenson's Treasure Island (1883) and H. Rider Haggard's King Salomon Mines (1886) - helped to create a revival of the form. Haggard crystallized the male adventure romance as a journey to a distant land, where the colonial explorer encounters an exotic civilization with bizarre customs that seem antithetical to the European way of life. Haggard's fiction added a new twist to the genre: «the journey to the imperial frontier becomes a journey into the past» (Cantor and Hufnagel, 2006:37). This formula was used by Wells in some of his fin-de-siècle narratives: the adventure romance involves an outward journey into the unknown and enforces a descent into the mind of the adventurer.

«The Country of the Blind» is intimately concerned with redemption through primitive reversion rather than material regression to a pastoral state: the traveller leaves the world of civilization and enters the world of the past. The challenges he has to face are physical as well as epistemological. The tale parodies the conventions of the imperial romance in order to undermine the ideologies of colonial domination (James, 2012:38). However, this story is also written through with a mythopoeic motif of redemption through contact with nature.

As the story opens, Wells (in the guise of the heterodiegetic narrator) creates a frame narrative that relates the history of a remote valley in the Andes, where all the inhabitants live in harmony. Fifteen generations earlier, the valley had been a haven for settlers fleeing the «lust and tyranny» of the Conquistadores who had invaded their land, until a terrible earthquake that reshaped the surrounding mountains isolated them forever from the outside world. The community prospered over the years despite a disease that struck them long ago, rendering all newborns blind. As blindness spread over many generations, the valley-dwellers' remaining senses sharpened; eventually they even forgot what «sight» was.

In this secluded valley, the blind natives have «all that the heart of man could desire - sweet water, pasture, an even climate, slopes of rich brown soil with tangles of a shrub that bore an excellent fruit» $(\mathrm{CoB} 722)$. All is peace and plenty in this Andean utopia until the arrival of Nunez, the ambitious mountaineer from the outside world- a man who has eyes and can see. According to the narrator, Nunez is a free and intelligent spirit, «a mountaineer from the country near Quito, a man who had been down to the sea and had seen the world, a reader of books in an original way, an acute and enterprising man» (CoB 725). During his attempt to lead an expedition of English climbers to Mount Parascotopetl, one of the highest peaks in the Andes, Nunez accidentally falls down a precipice and disappears in a blizzard: «he was lost to the outer world» (CoB 726). Nunez is reported dead, but survives his fatal fall with only a few cuts and bruises. Wells's protagonist initially sees the landscape as many before him: an earthly paradise, «a sanctuary of purity in the fallen world, often stylized as an Eden», which remains uncorrupted and bears close resemblance to utopian images throughout literary history (Boulton, 1995:6). With its South American setting, «the geography of imperialism» is reflected subtly throughout the narrative (Parrinder, 1995:86).

Nunez descends into the valley and finds a strangely urban community in miniature, a village with windowless houses and a network of paths, all bordered by curbs: «The 
good man who did that», he thought, «must have been as blind as a bat» (CoB 731). Welcomed by three blind peasants, he advances toward the tidy village with confident steps, while secretly fantasizing of how he can make himself absolute ruler of the fertile valley:

"Over the mountains I come," said Nunez, "out of the country beyond there-where men can see. From near Bogota, where there are a hundred thousands of people, and where the city passes out of sight."

"Sight?" muttered Pedro. "Sight?"

"He comes," said the second blind man, "out of the rocks." (CoB 733)

Upon discovering that all the villagers are sightless, Nunez begins reciting to himself the proverb «In the country of the blind, the one-eyed man is king». Keeping the old adage in mind, the sighted protagonist expects to become master among the blind, but events betray his expectations: «[h]is naïve ambition to teach the blind the practical value of sight is doomed to failure, because blindness is neither an evolutionary defect nor a hereditary disease: it is evolution, envisaged as regressive» (Coelsch-Foisner, 2008:177).

"There is no such word as see," said the blind man, after a pause. "Cease this folly, and follow the sound of my feet."

Nunez followed, a little annoyed.

"My time will come," he said.

"You'll learn," the blind man answered. "There is much to learn in the world."

"Has no one told you, 'In the Country of the Blind the One-eyed Man is King'?"

"What is blind?" asked the blind man carelessly over his shoulder. (CoB 743)

The macro-structure of this speculative story is a negation of the original proverb about the country of the blind, with echoes of Plato's Parable of the Cave, as well as a rewriting of the archetypal myth of a remote pastoral (e)utopia. The gift of sight so linked to the right to rule and the prominence of the personal pronoun «I» represent Nunez's imperial arrogance (Boulton, 1995:14).

"And you have come into the world?" asked Pedro.

"Out of the world. Over mountains and glaciers; right over above there, half-way to the sun. Out of the great big world that goes down, twelve days' journey to the sea." (CoB 735)

The man who «came into this community from the outer world» (CoB 725) offers a perfect metaphor for nineteenth-century European imperialism. The stranger from the outer world is literally thrown into the Other World (or Other Place, to use a term coined by Foucault). In essence, this young mountain guide becomes the very embodiment of the hegemonic world beyond the cliffs that isolate and protect the valley of the blind:

In the ideology of European domination, the land discovered was virgin earth because the explorer / imperialist does not recognize the ownership of land by its existing occupants [...] This concept is contained, by implication, in the naming of the land as found; to be found presumes that the possession was once lost. (Boulton, 1995:7) 


\section{2. «The Country of the Blind»: Aesthetic Antitheses}

The fascination of this story lies in the juxtaposition of two incongruous worlds, an essential device by which Wells can meditate on the contradictions inherent in the human condition. According to John Huntington, a number of his early short stories are built on binary oppositions as a fundamental structural element that is central to Wells's art: «the two-world structure itself shows up repeatedly as a pleasurable and energizing incongruity rather than an angle generating satire» (1981:241). The male-centred nature of these stories is invariably described in a series of aesthetic antitheses that follow the pattern of colonial romance: supremacy and subordination, civilization and nature, «Them» and «Us» (Liggins et al., 2013:91).

Literary narratives concerning the wandering of an outsider into a closed valley or strange land (heterotopia) are commonly found in the European literary tradition. By remaining faithful to the conventions of this tradition and sometimes inverting their suggestive symbolism, the early Wells explored contemporary issues of evolution and civilization through ironic use of myths. What according to the legend appears to be a pastoral utopia is denigrated by the inhabitants' blindness, «whose wonderfully refined senses of hearing, smell, and touch make them in some respect superior to the seeing man» (Koppenfels, 2004:163).

The relationship of the civilized man to language is also inverted. In the typical colonial adventure story the invader is a prophet whose power of language confers manhood upon him. In «The Country of the Blind» he is awarded the same status as the one he initially ascribes to the blind tribe, that of the backward or disabled: «[h]e is but newly formed. $\mathrm{He}$ stumbles as he walks and mingles words that mean nothing with his speech» (CoB 738). Another subtle suggestion is the inversion of day and night that makes sight virtually useless. Nunez is not open to knowledge, in the sense that his belief in the gift of sight is greeted with the same contempt as the blind greet the validity of his world: «Nunez's sense of superiority, which is both naïve and arrogant, turns back on him: the outsider who attempts to impose the shape of his culture on to the new world is humiliated and persecuted» (Coelsch-Foisner, 2008: 178). The man from the great city beyond the high mountains, the civilized man who would make himself a God-king and enlighten the blind and the backward, has instead become an obedient serf, a humble domestic slave. Significantly, he is himself renamed by the blind: «Trample not on the grass, Bogota; that is not allowed» (CoB 742); «Bogota! Put down that spade, and come off the grass!» ( $\mathrm{CoB} 750)$.

In «The Country of the Blind», both the blind and the sighted are viewed as defective for different reasons: «[p]art of Wells's genius is that he allows [us] to read both parties' arrogance and dogmatism» (Boulton, 1995: 16). Nunez refuses to accept that the inhabitants of the valley_ «these idiots» as he calls them (CoB 760) - have a simple agrarian system that supplies their needs. According to his logic, the primitive natives, eyeless, uneducated, and agrarian, should submit to his rule simply because he comes from a more advanced world. Travelers to remote corners of empire often had the impression that they were entering the world of the past: «[t]hey led a simple, laborious life, these people, with all the elements of virtue and happiness [...] They toiled, but not oppressively; they had food and clothing sufficient for their needs [...] and there was love among them, and little children» (CoB 744). 
The blind inhabitants are fixed in their established illusions. Like Plato's «cave men», the idea of any civilization outside the valley is incomprehensible to the villagers. And so they take Nunez for a madman: «[t]hey told him there were indeed no mountains at all, but that the end of the rocks where the llamas grazed was indeed the end of the world; thence sprang a cavernous roof of the universe, from which the dew and the avalanches fell» (CoB 746).

The blind natives refuse to believe Nunez's descriptions of the landscape, and ridicule his claim to vision and knowledge. To the blind, sight is deemed a sign of insanity and depravity: «You see, my dear, he's an idiot. He has delusions; he can't do anything right» (CoB 757). To the sighted protagonist, lack of sight is considered as a sign of inferiority and discrimination, whereas the gift of sight is perceived as virtuous and advanced: «You don't understand», he cried in a voice that was meant to be great and resolute, and which broke. «You are blind, and I can see. Leave me alone!» (CoB 750). Even after Nunez becomes the docile servant and responsible citizen, the blind people do not accept him as one of their own: «They held him as a being apart, an idiot, incompetent thing below the permissible level of a man... The young men were all angry at the idea of corrupting the race» (CoB 757). This statement ironizes and inverts the imperialist narrative. He experiences the rhetoric of racial purity that commonly has caused the indigenous population to be ostracized. The invader becomes the invaded.

When Nunez falls in love with his master's daughter, Medina-saroté, his eyes prove the only impediment to a marriage that would give him fully human status among the natives of the valley. For Nunez, the blind population has lost the light of the imagination: «[m]uch of their imagination had shrivelled with their eyes» (CoB 739). For the blind, Nunez's eyes are a nuisance — «those queer things» (CoB 759) — tumorous swellings, and «the symptom of a bodily and mental disease that prevents him from being fully integrated into their society» (Koppenfels, 2004:163-64). The elders agree to permit him to marry her if only he will consent to having his eyes removed in a simple surgical operation. The reader realizes that the attempt to blind Nunez, far from being a barbaric act, finds a justification among some of the tenets of imperial rhetoric.

It was Medina-saroté who persuaded Nunez to face the blind surgeons.

"You do not want me," he said, "to lose my gift of sight?"

She shook her head.

"My world is sight." (CoB 760) [My emphasis.]

On the day before the operation, Nunez flees the village by climbing the dangerous precipice surrounding the valley, searching for a passage through the mountain wall in order to go back to Bogotá. Thus Wells takes his hero to the scene of his death. He is last seen with a smile on his face, lying motionless on his back under the cold stars. Nunez's destiny is deftly encapsulated in the final paragraphs of the story, in which the narrative is no longer focalized through Nunez's consciousness. This descriptive passage alludes again to Plato's parable of the cave, but inverts its suggestive symbolism. The coda completes the circular pattern of the story, yet it also conveys a certain ambiguity and ambivalence. In the coda to the published text, a detached omniscient narrator repeats a number of motifs and visual impressions from the opening paragraphs: the sublimity of the sunset landscape in the high 
mountains, the glints of «light and fire», the vastness of the starlit sky and the reference to the proverb about the One-Eyed Man.

Wells's short story is mythopoeic in impulse, and crucially engages in a questioning of modernity and the value of scientism that draws his writing into alignment with fantasy fiction. This ironic utopia stands in a sceptical relation to dominant ideas of progress, which are challenged by the notion of degeneration from a past state based on a romantic interpretation of anthropological concepts regarding myth, nature, and primitive thought. As a prophet, Nunez is like Plato's prisoner who stumbles towards the light: he alone understands the real nature of the flickering shadows that his fellow prisoners see on the walls of the cave, but he cannot easily communicate his knowledge to them. Blindness and sight simply reverse definitions of supremacy and subordination, vision and obscurantism. The Menippean turn of perspective has transformed the «Happy Valley» into its own antithesis, or ironic utopia.

\section{WORKS CITED}

Bergonzi, Bernard (1961): The Early H. G. Wells: A Study of the Scientific Romances, Toronto, University of Toronto Press.

Boulton, Alex (1995): «The Myth of the New Found Land in H. G. Wells's "The Country of the Blind"», The Wellsian: The Journal of the H. G. Wells Society 18:5-18.

Cantor, Paul A. and Peter Hufnagel (2006): «The Empire of the Future: Imperialism and Modernism in H. G. Wells», Studies in the Novel 38: 36-56.

Coelsch-Foisner, Sabine (2008): «H. G. Wells's Short Stories: “The Country of the Blind" and "The Door in the Wall"», Malcolm, Cheryl A. and David Malcolm (eds.), A Companion to the British and Irish Short Story, Malden, Blackwell, pp. 174-182.

Hillegas, Mark R. (1967): The Future as Nightmare: H. G. Wells and the Anti-Utopians, New York, Oxford University Press.

Huntington, John (1981): «Thinking by Opposition: The 'Two-World' Structure in H. G. Wells's Short Fiction», Science-Fiction Studies 8: 40-254.

- (1982a): «Utopian and Anti-Utopian Logic: H. G. Wells and his Successors», Science-Fiction Studies 9: 122-146.

- (1982b): The Logic of Fantasy: H. G. Wells and Science Fiction, New York, Columbia University Press.

James, Simon J. (2012): Maps of Utopia: H. G. Wells, Modernity and the Ethics of Culture, Oxford, Oxford University Press.

Koppenfels, Werner (2004): «"These Irritant Bodies": Blinding and Blindness in Dystopia», The Cambridge Quarterly 33(2):155-172.

Liggins, Emma, ANDrew Maunder and Ruth Robbins (2013): The British Short Story, Basingstoke, Hampshire, Palgrave-Macmillan.

McConnell, Frank (1981): The Science Fiction of H.G. Wells, New York, Oxford University Press.

Orel, Henry (1986). The Victorian Short Story: Development and Triumph of a Literary Genre, Cambridge, Cambridge University Press.

Page, Michael R. (2012): Literary Imagination from Erasmus Darwin to H. G. Wells: Science, Evolution, and Ecology, Farnham, Surrey, Ashgate Publishing Group.

PARrinder, PAtrick (1990): «Wells's Cancelled Endings for "The Country of the Blind"», Science Fiction Studies 17(1):71-76. 
Parrinder, Patrick (1995): Shadows of the Future. H. G. Wells, Science Fiction, and Prophecy, Syracuse, Syracuse University Press.

Stableford, Brian (1985): Scientific Romance in Britain, 1890-1950, New York, St. Martin's Press.

Suvin, Darko (1979): Metamorphoses of Science Fiction: On the Poetics and History of a Literary Genre, New Haven and London, Yale University Press.

ThOmpson, Terry W. (2004): «"I Come from the Great World": Imperialism as Theme in Wells's "The Country of the Blind"», English Language Notes 42(1): 65-75.

- (2011): «Exterminating Brutes: Subjugation as Subtext in H. G. Wells's "The Country of the Blind"», South Carolina Review 43(2):137-144.

Wells, Herbert G. (2008): The Country of the Blind and Other Stories [1911], Portland, The Floating Press. 
